\title{
Fundamental Environmental and Landscape Forming Influence of Close Grass Cenosis on the Moisture Circulation
}

\author{
Alexander Y. Rakov \\ The Stavropol State Scientific Institution of Agriculture, Stavropol, Russia \\ Email: rakov_au@mail.ru
}

Received February 21 $1^{\text {st }}, 2012$; revised March $25^{\text {th }}, 2012$; accepted April $8^{\text {th }}, 2012$

\begin{abstract}
The condensation of transpiration and advective water fallows (further-the phenomenon) under the close grass cenosis can be compared to the quantity of precipitation. The phenomenon depends on physical and meteorological features of the closed grass cover. For instance, close grass cover halts a large part of solar radiation at the daytime. Effective emanation and turbulent exchange cool the soil to a dew point and lower. The phenomenon forms another landscape. There are also a number of other fundamental consequences of the phenomenon. Thus, biologolisation of farming and forestry: Growing of forests and agrocenosis with grasses (present-day weeds) that may serve as activators for forests and grasses; Cultivated plants selection, allelopathically compatible to some definite weeds; as a result of such a selection weeds may be found and transformed into activators. To fight against drought, desertification the importance of the phenomenon is obvious. Flooding in the Western Europe may be connected with the named phenomenon as this resource in connection with climate change is, probably, growing.
\end{abstract}

Keywords: Condensation; Transpiration; Fundamental Consequences

\section{Introduction}

It is very important to define the elementary unit of (agro) landscape-facies, as an atom in physics or a molecular in chemistry. Sukachyov (1972), Ramensky (1971) have shown the leading part of vegetation in such allocation. Beruchashvili (1990) has proved the geophysical approach to this allocation: facies' borders are the lines dividing territories with different fito-, geo- and energy mass - solar and other kinds of energy, vegetation, soil, hydro- and geology.

As for agrolandscape, such an approach is the most rational. It is obvious that borders of agrofacies are the borders of crop rotation fields. As a result, agrofacies, as well as crop rotation fields, are changing not only in space, but also in time.

Main phyto- and geomass in agricultural production is crop. At the beginning of the XX-th century wheat yield of $6-8$ hundredweight per hectare was considered as a good crop. Nowadays in droughty steppes wheat yield reaches 60 - 80 hundredweight per hectare without an irrigation that is equivalent to 18 - 24 hundredweight per hectare of general dry organic substance. Even if we take into consideration all the precipitation during a year, for example $500 \mathrm{~mm}(0.5 \mathrm{~m}$-forest-steppe $)$ and refer to this crop quantity, the final field transpiration coefficient will make only $0.5 \times 10^{4}$ hundredweight per hectare precipitation forest-steppe tons of water $\div 18$ or $24=208-278$, where $10^{4}$ is the area of 1 hectare in square metres and $\div$ is a division mark.

At the same time all the irrational expenses are ignored: expenses on evaporation, drainage, filtration. This elementary mathematics shows that except precipitation there is another very powerful source of humidifying. In our opinion, this source of humidifying is, first of all, the condensation of transpiration vapour at the daytime. While cooling the active surface by effective emanation, turbulent exchange and with the flow of humid air: before and during the precipitation at the vegetation period and in winter at advection of warm humid air - the process of water vapour condensation is being amplified by the mentioned advection.

It is also well-known that a close grass cover and a water vapour halt a large part of solar radiation. All these factors together create a favorable conditions for condensation of transpiration and advective water vapours in soil (further the phenomenon) under the herbage.

The majority of researchers conclude the insignificant quantity of the phenomenon in soils without herbage. But Koloskov (1937) has assumed the possibility of the advective fallow condensation after strong cooling of the soil and the transpiration fallow at the daytime under the quite strong productive herbage, considering the latter not as the coming of water, but as the savings of discharged water from soil. Indirectly this phenomenon is proved by a strong variation of field transpiretion coefficient within one crop. This hypothesis is proved by of Izmailsky (1949) at the end of the XIX-th century, who has defined that the soil under more productive crop cenosis is damper during a year in comparison to the less productive degraded virgin soil.

As for foreign authors, R. Sleiter and I. Mackelroy (1964) asserted that the maximum possible dew takes place under a high bushy vegetation in deeply mulched soil. In their opinion the quantity of maximum condensation (-Emax) is proportional to radiation balance and was determined by the following formula:

$$
(-\mathbf{E}) \max =(\mathbf{s} \div(\mathbf{s}+\gamma)) \times / \mathbf{R} \div \mathbf{L} /,
$$

where $\mathbf{s}-$ the quantity connected with specific moisture; $\gamma$-psychometric constant;

$/ \mathbf{R} \div \mathbf{L} /$ - the module of the radiation balance relation to the latent heat of vaporization;

$\div$ and $\times$ —division and multiplication marks. 
It is necessary to underline that the radiation balance is defined, first of all, by a daytime solar radiation.

According to the researchers, quantity $(s \div(\mathrm{s}+\gamma))$ varies from 0.4 to 0.8 and the condensation rating can reach hundreds in $\mathrm{mm}$.

\section{Research Technique}

To study this phenomenon not analytical, as before, but synergetic approach is acceptable: soil and plant are integration. Researches were carried out in 3 agroclimatic zones of the Stavropol territory: the extremely droughty (I zone: Achikulakskaya scientific research experimental forestry stationSREFS), droughty (II zone: Prikumsky experimental breeding station-PEBS and the Limited Liability Company "Stavropol-Caucasian") and insufficient moistening area (III zone: the experimental production farm "Mikhailovskoe" and the educational farm of the Stavropol State Institute of Agriculture). At first moisture measurements in different agrolandscapes were carried out by a thermostatic weight method at a depth of 11,5 $\mathrm{m}$, then by a neutron moisture measurement - up to $25 \mathrm{~m}$. The data were processed by computer programs - statistically. The total loss of moisture (balance): all the precipitation from the moment of crops sowing plus loss of moisture from the observed soil profile were referred to all the crop. The dew point of the air under the herbage was defined and then compared to the soil temperature. The possibility of the phenomenon was defined lysimetrically and by difference calculation of accepted transpiration and field coefficients (TC and FC), that is [450 $208(278) \times 18(24)] /=310$ or $581 \mathrm{~mm}$. Values in brackets mean variations, $\times-\mathrm{a}$ multiplication mark. The results of the researchers are resulted in Table 1.

The general crop of dry organic substance of agricultural crops is equal to the tripled grain yield, doubled hay yield or dry above-ground mass. Tables $\mathbf{1}$ and $\mathbf{2}$ are interconnected: from the data of the first one the data of the second follows.

\section{Results of Researches}

We (Rakov and others, 1982, 1994, 1997, 2004, 2007, 2008, 2009) have proved the hypotheses of Koloskov (1937), R. Sleiter and I.Mackelroy (1964) of the possible importance of tran- spiration or advective water fallows condensation and the simultaneous display of these processes.

The analysis of soil temperature and dew point according to our data (Rakov, 2004, 2008) and the data described in literature (Shulgin, 1972) shows their favorable combination under the close herbage for the named phenomenon beginnings. Under it the soil temperature $\left(12^{\circ}-18^{\circ}\right)$ at the daytime at the depths to $30 \mathrm{sm}$, as a rule, is lower or is equal to a dew point $\left(13^{\circ}-21^{\circ}\right)$ at the $10 \mathrm{~cm}$ height of the soil surface.

It is known that soil thermal capacity and heat conductivity is high enough that promotes the heat abstraction, allocated at condensation.

The most favorable conditions for the phenomenon take place during the downpours and after them under the vegetating close herbage, because: 1 ) the soil is cooled not only by effective emanation, but especially intensively by a wind, precipitation, physical evaporation (a turbulent exchange); 2) intensive advective fallow of atmosphere is raising a dew point; 3 ) thermal capacity and heat conductivity of soil are at maximum.

It is proved by experimental data: while precipitation the moisture level under the close herbages often exceeded their quantity and ground waters have raised. Minimum accumulation of a moisture during the autumn-winter period in observed profiles was marked as well (for example, from 04.09.72 to 14.03.73 in Achikulakskaya SREFS). We connect it with the establishing of equilibrium state since autumn (Rakov, 1997, 2004). This state hides the condensation phenomenon, especially during the vegetation period.

The most considerable moisture losses take place after harvesting and during cultivations that is typical for all our observations (Table 2).

Lysimetrical measurements also helped to establish the fact that there are periods when to a lysimeter with the model of surrounding soil under the close herbage comes more water, than it comes to a soil raingauge. It is possible only at the expense of condensation of advective or transpiration water fallows or each of them together. The quantity measured in such a way is reduced by physical evaporation. However quantities (45.9 - $75 \mathrm{~mm}$ ) were received comparable to precipitation that is proved statistically (Rakov, 1982, 2004).

Possibility and importance of moisture condensation quantity

Table 1.

Field transpiration index and phenomenon rating depending on crop and yield under multi closed grass.

\begin{tabular}{|c|c|c|c|c|c|c|c|c|}
\hline Place, area*, year & $\begin{array}{l}\text { Ground layer, } \\
\mathrm{m}\end{array}$ & Crop & $\begin{array}{r}\text { General } \\
\text { yield } \mathrm{h} / \mathrm{h}\end{array}$ & $\begin{array}{c}\text { Precipitation, } \\
\mathrm{mm}\end{array}$ & $\begin{array}{c}\text { Precipitation balance, } \\
\mathrm{mm}^{* * * *}\end{array}$ & $\mathrm{TC}$ & $\mathrm{FC}$ & $\begin{array}{c}\text { Phenomenon } \\
\text { rating, mm }\end{array}$ \\
\hline LLC “Stavropol-Caucasian”, II, 2007 & $0-1$ & Winter wheat & 18.7 & 366 & -466 & 450 & 249 & 376 \\
\hline $\begin{array}{l}\text { Achikulakskaya } \\
\text { SREFS, I, } 1972\end{array}$ & $0-4$ & Winter rye & 6.7 & 201 & -136 & 500 & 203 & 199 \\
\hline The same, 1973 & $0-4$ & Virgin lands hay & 0.6 & 184 & -214 & - & 3567 & 0 \\
\hline EPF “Mikhailovskoe”, III, 1987 & $0-7$ & Silage corn & 6 & 81 & +182 & 325 & $-303^{* *}$ & 377 \\
\hline The same & $0-9$ & The same & 10 & 390 & -171 & 325 & 171 & 154 \\
\hline The same, 1988 & $0-7$ & Triticale & 7.7 & 430 & -251 & 475 & 326 & 115 \\
\hline PEBS, II, 1993 & $0-24$ & Winter wheat & 8 & 316 & -274 & 450 & 342 & 86 \\
\hline The same, 1993 & $0-24$ & Winter barley & 8 & 316 & -184 & 258 & 230 & 22 \\
\hline The same ${ }^{* * *}, 1996$, May & $0-24$ & Winter barley & 5 & 195 & -106 & 258 & 212 & 23 \\
\hline
\end{tabular}

Notes: areas: ${ }^{*}$ I: extremely droughty, II: droughty, III: of insufficient moistening; ${ }^{* *}$ under the silage corn with the abundance of weeds FC became zero due to the phenomenon; ${ }^{* * * *}$ per verdurous masses; ${ }_{* * * *}$ one should take into account loss of moisture from the profile of Table 2. 


\section{A. Y. RAKOV}

Table 2.

Moisture balance depending on the biomass.

\begin{tabular}{|c|c|c|c|c|c|c|}
\hline Date & Crop & $\begin{array}{c}\text { Yield COB, } \\
\text { hundredweight per hectare }^{*}\end{array}$ & $\begin{array}{l}\text { Rainfall for the period, } \\
\mathrm{mm}\end{array}$ & $\begin{array}{c}\text { Total moisture, } \\
\mathrm{mm}\end{array}$ & $\begin{array}{c}\text { Moisture balance, } \\
\mathrm{mm}\end{array}$ & $\begin{array}{l}\text { Ground water } \\
\text { level/profile, } \mathrm{m}\end{array}$ \\
\hline 1 & 2 & 3 & 4 & 5 & 6 & 7 \\
\hline \multicolumn{7}{|c|}{ Achikulakskaya SREFS } \\
\hline 05.09 .72 & virgin lands & 0 & & 326 & & $-/ 0-4$ \\
\hline 07.03 .73 & virgin lands & 0 & 82 & 397 & -11 & $-/ 0-4$ \\
\hline 26.06 .73 & virgin lands & 0.6 (hay) & 184 & 367 & -214 & $-/ 0-4$ \\
\hline 11.10 .73 & virgin lands & 0 & 114 & 260 & -221 & $-/ 0-4$ \\
\hline 20.09 .71 & winter rye & corn shoots & & 320 & & \\
\hline 28.03 .72 & winter rye & till 1,0 & 185 & 456 & -49 & $-/ 0-4$ \\
\hline 24.05 .72 & winter rye & 6.7 & 16 & 385 & -87 & $-/ 0-4$ \\
\hline 26.06 .72 & Mowed & $0.3^{* *}$ & 42 & 337 & -90 & $-/ 0-4$ \\
\hline 23.08 .72 & "Mowed" & 0 & 95 & 308 & -124 & $-/ 0-4$ \\
\hline \multicolumn{7}{|c|}{ Experimental production farm "Mikhailovskoe" } \\
\hline \multirow{2}{*}{$30.06-16.07 .87$} & \multirow{2}{*}{ silage corn } & till 0,5 & & 1477 & & $7.7 / 0-7$ \\
\hline & & 6 & 81 & 1740 & +182 & $2.9 / 0-7$ \\
\hline \multirow{2}{*}{$30.04-02.09 .87$} & \multirow{2}{*}{ the same } & crops & & 1158 & & $-/ 0-9$ \\
\hline & & 10 & 390 & 1377 & -171 & $-/ 0-9$ \\
\hline 1 & 2 & 3 & 4 & 5 & 6 & 7 \\
\hline 12.08 .87 & Mowed & 0 & 29 & 1589 & -180 & $4.7 / 0-7$ \\
\hline 03.05 .88 & Triticale & 1.5 & 366 & 1596 & -359 & $6.7 / 0-7$ \\
\hline 11.05 .88 & Triticale & 2.6 & 34 & 1691 & +61 & $7.0 / 0-7$ \\
\hline 30.05 .88 & Triticale & 7.7 & 30 & 1768 & +47 & $3.4 / 0-7$ \\
\hline \multicolumn{7}{|c|}{ Prikumskaya experimental breeding station } \\
\hline 07.12 .90 & virgin lands & 0 & & 2555 & & $-/ 0-24$ \\
\hline 17.04.91 & virgin lands & 0.5 (hay) & 116 & 2630 & -41 & $-/ 0-24$ \\
\hline 22.05 .91 & virgin lands & 0.5 (hay) & 84 & 2623 & -91 & $-/ 0-24$ \\
\hline 04.07 .91 & virgin lands & 0.5 (hay) & 137 & 2649 & -163 & $-/ 0-24$ \\
\hline 07.08 .91 & virgin lands & 0.5 (hay) & 15 & 2584 & -80 & $-/ 0-24$ \\
\hline 21.10 .92 & winter barley & 1.0 & & 3252 & & $-/ 0-24$ \\
\hline 28.04 .93 & winter barley & 3.0 & 178 & 3404 & -26 & $-/ 0-24$ \\
\hline 24.06 .93 & winter barley & 8.0 & 138 & 3384 & -158 & $-/ 0-24$ \\
\hline 24.08 .93 & harvested & 0 & 143 & 3309 & -218 & $-/ 0-24$ \\
\hline 30.10 .95 & winter barley & 1.0 & & 3333 & & $-/ 0-24$ \\
\hline 22.04 .96 & winter barley & 3.0 & 153 & 3369 & -117 & $-/ 0-24$ \\
\hline 21.05 .96 & winter barley & 5.0 & 42 & 3422 & +11 & $-/ 0-24$ \\
\hline 17.07.96 & harvested & 0 & 74 & 3326 & +22 & $-/ 0-24$ \\
\hline 23.10 .96 & hulling & 0 & 57 & 3323 & -60 & $-/ 0-24$ \\
\hline 20.10 .92 & winter wheat & 1.0 & & 2926 & & $-/ 0-24$ \\
\hline 26.04 .93 & winter wheat & 3.0 & 178 & 2885 & -219 & $-/ 0-24$ \\
\hline 1 & 2 & 3 & 4 & 5 & 6 & 7 \\
\hline 23.06 .93 & winter wheat & 8.0 & 138 & 2968 & -55 & $-/ 0-24$ \\
\hline 23.08 .93 & Hulling & 0 & 143 & 2910 & -201 & $-/ 0-24$ \\
\hline \multicolumn{7}{|c|}{ LLC "Stavropol-Caucasian" (according to M. A. Sirota) } \\
\hline 2006-2007 & winter wheat & 18.7 & 366 & $100^{* * *}$ & -466 & $-/ 0-1$ \\
\hline $2007-2008$ & winter barley & 20.8 & 361 & $96^{* * *}$ & -457 & $-/ 0-1$ \\
\hline
\end{tabular}

Notes: ${ }^{*}$ all the dry organic substance; ${ }^{* *}$ after-grass. 
of precipitation in soil are proved by calculations of field transpiration factors (FTF) when for the volume of received yield all the spent moisture is referred, including physical evaporation. In spite to it their quantity under close productive herbages in many cases appears to be much less than common obviously genetic EC (according to (Grodzinsky, 1972) - minimum quantities were taken into consideration). It is possible only if the named phenomenon has a considerable quantity, that varied at such definition from 0 to $430 \mathrm{~mm}$ (Table 1). With the quantities of the phenomenon, comparable to precipitation, fundamentally different landscapes are formed as it was mentioned above.

Protective forest plantations themselves drain the soil during the vegetation (Rakov, 2004, 2007); at the same time they provide spatial ameliorative effect on adjoining lands. The formation probability of close herbages with considerable quantity of the transpiration and advective water fallows phenomenon in soil is the greatest in the system of protective forest plantations. It is well illustrated by a yield of winter crops (60 - 70 hundredweight per hectare) in the "Stavropol-Caucasian" LLC at the southern chernozems in the 2nd droughty zone without an irrigation. This yield two times exceeds an average yield for the last several years that considered to be rather productive (Table 2).

FC varies depending on capacity of an observed soil profile on moisture and the received yield. For winter wheat it varied from 249 to 342 . For rye and triticale - from 203 in the first zone to 326 - in the third that shows great moisture accumulation role of close herbage, especially during the time of intensive precipitation; in the case of winter barley FC decreased to 212. It had initially minimal FC, most likely being field but not genetically caused. For corn with an abundance of weeds FC appeared to be negative as its density reached $100 \%$. Under this corn (one should bear in mind the abundance of weeds and heavy precipitation) was marked considerable accumulation of moisture: level of ground waters has risen from 8 to $2.9 \mathrm{~m}$ (Rakov, 2004). The rating of the phenomenon (Table 1) has changed accordingly. Under the corn without weeds, but with more yield volume FC has increased to 171. The rating of the phenomenon has made $154 \mathrm{~mm}$.

According to the received results it is possible to assume that close herbage at plentiful precipitation functions, mainly, due to the condensate moisture as in this case the sucking potential of plants is minimum. The moisture $t$ moves transit to the soil depth till the ground waters, raising their level. Moisture supply in this case sometimes even surpassed quantity of precipitation

\section{Discussion}

The phenomenon has multipurpose value for sciences about the Earth and on the earth: rationalization (farming biologilization) and especially for landscape studying (Rakov et al., 2009).

And particular for:

- landscape studying - the previous and following examples shows the landscape changes under the influence of the named phenomenon. More rational seems to be mentioned above geophysical approach (Beruchashvili, 1990). Differently productive cenosis are different facies - units of a landscape. This is especially rational for the agro landscape. At the beginning of the last century the winter wheat yield of 40 - 50 poods ( 8 hundredweight per hectare) was a good crop. Now in Russia yields of $60-80$ hundredweight per hectare are possible mainly thanks to the named phenomenon, selection, etc.; and this is different agro facies. Now let us consider some examples on a landscape transformation by a plant. Some badlands were formed on a plain (because of the secondary salinization of soil) and on a slope (the soil was ploughed up along a slope). By means of methods and plant kinds of the Stavropol Scientific Research Institute of Agriculture badlands have been transformed into productive lands - so quite the different agro facies have been formed. But according to the accepted theory of a natural landscape the name of facies remained unchangeable though it contradicts the common sense-they are called $a$ plain and $a$ slope as before.

An irrigation - in addition to other reasons of water losses, because of ignorance of the named phenomenon the majority of the irrigated soils are impounded and subjected to secondary salinization.

- Forestry - after the deforestation in zones of excessive moistening in glades swamps are formed. To avoid this an immediate afforestation is necessary.

- Gardenings - it is necessary to find grass cenosis with an abundance of entomophages to avoid chemistry downward seepage.

- Selections, plant growing - it is rational to output the plant varieties that are allelopathically compatible to some present-day weeds. They will serve as activators for cultivated plants. For example, wheat together with the annual lucerne have already been grown for a long time in China. Chemistry application will be reduced. And so on.

To fight against drought, desertification the importance of the phenomenon is obvious. Flooding in the Western Europe may be connected with the named phenomenon as this resource in connection with climate change is, probably, growing (Rakov, 2007)

\section{REFERENCES}

Beruchashvili, N. L. (1990). Landscape geophysics. Moscow: Higher school Publishing.

Grodzinsky, A. M., \& Grodzinsky, D. M. (1973). Reference guide on plant physiology. Kiev: Naukova dumka Publishing.

Izmailsky, A. A. (1949). The soil humidity and ground water in connection with relief and the cultural condition of the soil surface. Selected Works, Moscow, 83-335.

Koloskov, P. I. (1937). The natural conditions of intrasoil condensation: Issues of phisical geography. Vol. 4, Moscow: Leningrad, 169-202.

Rakov, A. Y. (1982) Soil condensation of water vapor in connection with climatic and phitocenosis conditions. Soil Science, 2, 74-78.

Rakov, A. Y. (1994). Special features in dynamics of soil humidity at phytomelioration of farm lands (on an example of the Stavropol territory). In A. Y. Rakov, A. N. Abaldov, A. A. Fedotov (Eds.), News of Science Academy of the USSR (pp. 68-79), Moscow: Russian Academy of Sciences.

Rakov, A. Y. (1997) Transpiration and advective water fallows condensation, ground water formation, equilibrium moisture content in the steppe soils. Soil Science, 12, 74-78.

Rakov, A. Y. (2004). Specific features of land phytomelioration in Central and East Ciscaucasia. Stavropol: Stavropol Research Institution of Agriculture.

Rakov, A. Y. (2007). Specific features of land phytomelioration in Central and East Ciscaucasiar. Abstract of Doctoral Thesis, Volgo$\operatorname{grad}, 47 \mathrm{p}$.

Rakov, A. Y. (2008). Land phytomelioration as a mean of the global ecological problems solving. Agricultural and food complex of Russia: tendencies, prospects, prioriteties. Saratov: The Russian Acad- 


\section{A. Y. RAKOV}

emy of Sciences, 263-265.

Rakov, A. Y., Tsygankov, A. S., \& Sirota M. A. (2009). Agrolandscape role of grass cenosis, forest strips, hydraulic engineering constructions and other natural boundaries. Moscow: The Russian Agrarian Sciences Academy, 27-29.

Ramensky, A. G. (1971). The selected works: Problems and methods of studying vegetation. Leningrad: Science Publishing.

Sleiter, P., \& Mackelroy, I. (1964). Practical microclimatology. Mos- cow: Progress Publishing.

Sukachyov, V. N. (1970). The selected works. Leningrad: Science Publishing.

Sukachyov, V. N. (1972). Physiology. Moscow: The Moscow State University Publication.

Shulgin, A. M. (1972). Soil climate and its regulation. 2nd Edition. Leningrad: Hydro Meteoizdat Publishing. 